\title{
HIDUP BERDAMPINGAN DENGAN HIDUPAN LIAR DI MASA PANDEMI COVID-19 (INTERAKSI DENGAN PEMIRSA PRO2 FM RRI MANOKWARI)
}

\section{Living Side by Side with Wildlife in the Pandemic Covid-19 (Interaction with Pro2 FM RRI Manokwari Listeners)}

\author{
Freddy Pattiselanno ${ }^{1)^{*}}$, Johan F. Koibur ${ }^{1)}$, Hotlan Manik ${ }^{1)}$, Dwi Djoko Rahardjo ${ }^{2)}$ \\ ${ }^{1)}$ Sub-Laboratorium Satwa Harapan, Fakultas Peternakan Universitas Papua, Manokwari \\ ${ }^{2)}$ Sub-laboratorium Nutrisi Ternak, Fakultas Peternakan Universitas Papua, Manokwari
}

Article history

Received: Dec 20, 2020;

Accepted: Feb 3, 2021

* Corresponding author:

E-mail:

f.pattiselanno@unipa.ac.id

DOI: https://doi.org/

10.46549/igkojei.v2i1.170

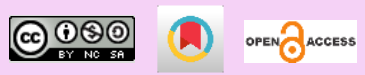

\begin{abstract}
Culturally, the relationship between the people and wild animals in Papua is close-knitted and inseparable. In response to this, through the Manokwari Menyapa program of RRI Manokwari, we share information about the current relationship between people and wildlife during the Covid-19 pandemic. This community service activity is carried out through radio broadcasts, which is an interactive program between listeners and informants on Monday, July 20, 2020. Listeners' responses vary widely including the impact of consuming animal meat, keeping animals as pet animals, and the consequences of forest loss to the intense exposure of animals to the people. Another thing that was revealed was the extent of the role of academics in efforts to reduce the current spread of the Covid-19 virus. This activity shows that the dissemination of information through electronic media (radio) related to the issue of the Covid-19 epidemic is very good and effective. The media's wide reach for people who can follow the radio broadcasts of RRI Pro2FM Manokwari benefits this program so much. This activity provides input to us regarding the public's understanding of the Covid-19 pandemic and the proper follow-up actions that should be considered by the authorities to reduce the spread of the Covid-19 virus in the community. Intense dissemination of information about the Covid-19 virus now needs to be done as an effort to raise awareness for ordinary people who do not understand well the dangers of this virus for human health.
\end{abstract}

Keywords: Covid-19; RRI listeners; Manokwari Menyapa

\section{ABSTRAK}

Secara kultural, hubungan manusia-satwa liar (hewan) di Papua sangat erat dan tidak dapat dipisahkan. Menyikapi hal tersebut, melalui program Manokwari Menyapa RRI Manokwari, kami berbagi informasi tentang hubungan antara manusia dan hidupan liar di masa pandemik Covid-19. Kegiatan pengabdian pada masyarakat ini dilakukan melalui siaran radio yang merupakan program interaksi antara pendengar dengan nara sumber pada hari Senin, 20 Juli 2020. Respon pendengar sangat bervariasi termasuk dampak mengkonsumsi daging satwa, memelihara satwa sebagai hewan kesenangan, serta akibat kehilangan hutan terhadap ekspose satwa yang sangat intens dengan manusia. Hal lain yang terungkap adalah sejauh mana peran akademisi dalam upaya mengurangi penyebaran virus Covid-19 saat ini. Kegiatan ini menunjukan bahwa penyebaran informasi melalui media elektronik (radio) berkaitan dengan isu pendemi Covid19 ini, sangat baik dan efektif karena jangkauannya yang luas bagi masyarakat yang bisa mengikuti siaran radio RRI Pro2FM Manokwari. Kegiatan ini memberikan masukan kepada kita bagaimana pemahaman masyarakat terhadap pandemik Covid-19, dan tindak lanjut yang perlu dilakukan oleh pihak-pihak 
berwenang untuk mengurangi penyebaran virus Covid-19 di masyarakat terutama yang berhubungan dengan hidupan liar. Penyebaran informasi tentang virus Covid-19 secara intens saat ini perlu dilakukan sebagai upaya penyadartahuan bagi masyarakat awam yang belum memahami dengan baik bahayanya virus ini bagi kesehatan manusia.

Kata kunci: Covid-19; Pemirsa RRI; Manokwari Menyapa

\section{PENDAHULUAN}

Dalam sejarah modern, tidak ada tantangan yang lebih besar bagi ekonomi global daripada COVID-19, virus korona SARS-2-COV baru (McNamara et al., 2020). WHO telah menetapkan COVID-19 sebagai pandemi atau wabah penyakit global. Penyakit baru ini dipercaya sebagai sumber virus baru Corona yang berawal di Kota Wuhan, Tiongkok akhir tahun 2019 dan telah menyebar luas ke seluruh dunia seperti dilaporkan oleh pemerintah China secara resmi kepada WHO (https://www.bbc.com/indonesia/dunia-52977852). Baru-baru ini Profesor Huabin Zhao (College of Life Sciences, Wuhan University) menginformasikan tentang dampak COVID-19 dan persepsi pemerintah dan publik tentang kelelawar (Zhao, 2020). Secara khusus, kelelawar telah berperan dalam sejarah evolusi sindrom pernapasan akut parah (SARS) - virus CoV-2, sekaligus mengindikasikan kaitan erat antara virus tersebut dengan satwa liar yang dijual di pasar Wuhan dengan (Wijaya, 2020).

SARS-CoV-2 adalah jenis penyakit zoonotik yaitu, penyakit yang berasal dari satwa liar atau domestik yang berpindah (spillover) ke manusia atau sebaliknya. Oleh karena itu, para ahli dan peneliti kerap memperingatkan berbagai resiko penularan penyakit zoonotik sebagai dampak dari berbagai akitivitas manusia yang berkaitan dengan satwa, seperti perburuan, perdagangan dan konsumsi. Hal mana sejalan dengan dengan hasil dari berbagai kajian selama dua dasawarsa terakhir ini yang mengungkapkan bahwa lebih dari $70 \%$ penyakit infeksi baru berasal dari satwa liar. Dari segi kesehatan, sudah terbukti bahwa selain satwa hasil buruan dan perdagangan merupakan reservoir atau medium tumbuh dan berkembang biaknya serta menyebar zoonosis. Selain itu juga mereka dapat berfungsi sebagai perantara carrier yang berdampak pada kesehatan manusia secara global.

Spot informasi tentang penyebaran Covid-19 yang dirilis RRI Jakarta ke setiap RRI di dearah merupakan penyampaian informasi pembelajaran kepada pemirsa RRI di manapun berada termasuk di Manokwari. Di Manokwari, ketika spot tentang Covid-19 ini mulai disiarkan, ada banyak respon yang diberikan oleh warga masyarakat kepada RRI PRO2 FM Manokwari. Menyikapi hal tersebut, dalam bincang-bincang informal dengan bagian penyiaran RRI Manokwari, disepakati bersama kami dari Sub-Laboratorium Satwa Harapan berbagi informasi tentang hubungan antara manusia dan hidupan liar saat ini di masa pandemik Covid-19 (Gambar 1). 


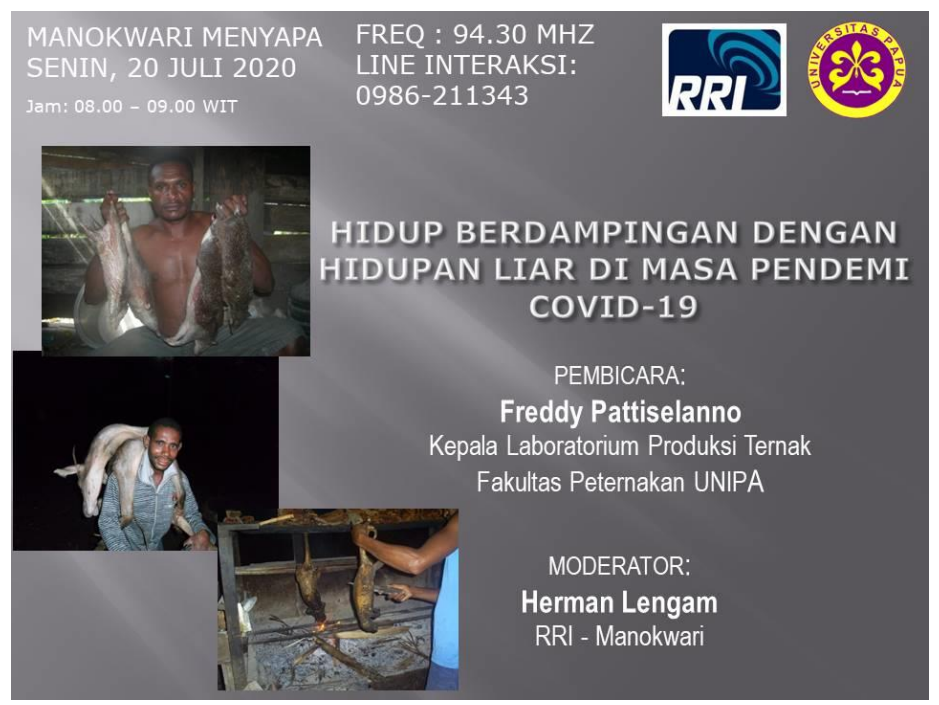

Gambar 1. Leaflet kegiatan yang disebarluaskan melalui media sosial Facebook.

Hasil interaksi dengan pendengar Pro2FM Manokwari melalui program Manokwari Menyapa disampaikan secara detail dalam tulisan ini.

\section{METODE}

Kegiatan pengabdian pada masyarakat ini dilakukan melalui program siaran Manokwari Menyapa RRI Pro2FM. Kegiatan ini merupakan program interaksi antara pendengar dengan nara sumber yang sudah dijadwalkan dalam program tersebut. Kegiatan dilakukan pada hari Senin, 20 Juli 2020 sesuai dengan jadwal dimulai pada jam 08.00 sampai dengan selesai. Tema yang disampaikan dalam kegiatan Manokwari Menyapa adalah "Hidup berdampingan dengan hidupan liar di masa pademi Covid-19” yang dipandu oleh penyiar senior RRI Manokwari Bapak Herman Lengam (Gambar 2).

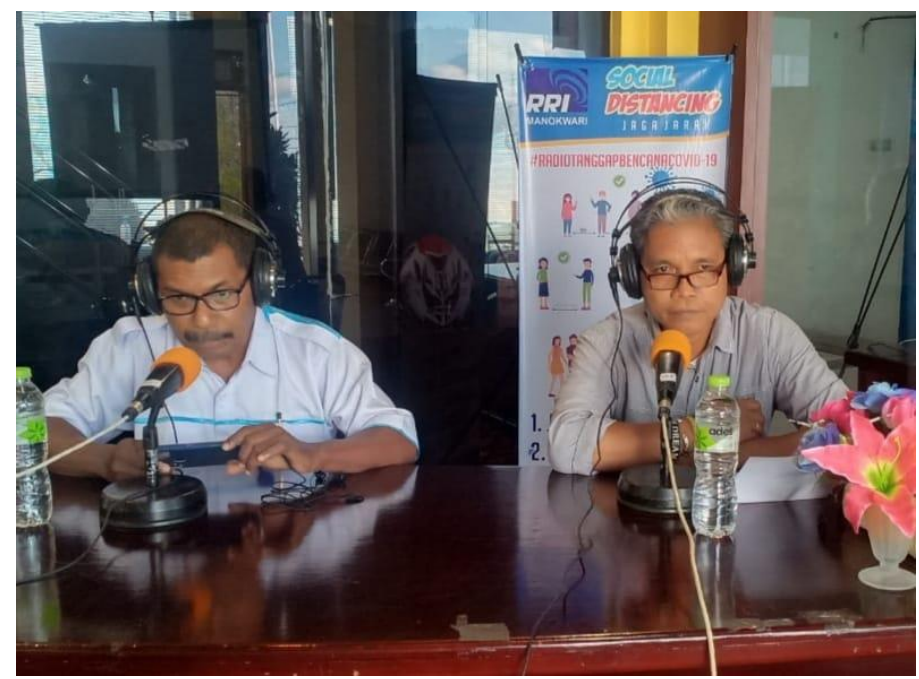

Gambar 2. Suasana saat siaran berlangsung di ruang studio RRI Pro2FM Manokwari

Narasi awal tentang isu yang disampaikan dalam episode tersebut telah ditayangkan oleh RRI, kemudian sambil menunggu respon pendengar, pemandu dan nara sumber berdiskusi tentang isu 
dimaksud. Setelah menerima tanggapan dari pendengar, nara sumber diberikan kesempatan untuk merespon tanggapan yang diberikan.

\section{HASIL DAN PEMBAHASAN}

\section{HUBUNGAN MASYARAKAT DI PAPUA DENGAN SATWA LIAR}

Perlu diketahui bersama, bahwa di Papua, hubungan manusia-satwa liar (hewan) sangat erat dan tidak dapat dipisahkan. Secara kultural hal ini tergambar dari pemberian nama beberapa lembaga (Pattiselanno, 2017), misalnya perguruan tinggi negeri pertama di Tanah Papua, Universitas Cenderawasih. Komando Daerah Militer Cenderawasih di Jayapura-Papua dan Kasuari di Manokwari-Papua Barat. Bagi masyarakat di Papua Barat, lambang atau logo Kabupaten Manokwari yang adalah burung Mambruk dan Papua Barat burung Kasuari memperkuat hal ini. Hal ini cukup beralasan, karena hidupan liar Papua tergolong sakral, unik dan diklasifikasikan sebagai spesies karismatik. Dari aspek ketahanan pangan, di daerah pedalaman dimana akses terhadap daging ternak (sapi, kambing dan ayam) terkendala kondisi geografis, ketergantungan terhadap sumber protein hewani non-ternak (daging satwa) sangat tinggi (Pattiselanno, 2006). Satwa liar juga merupakan hewan kesayangan yang dipelihara secara intensif di beberapa daerah di Papua (Pattiselanno, 2013; Koibur et al., 2015).

\section{MENGAPA COVID-19 SANGAT MUDAH TERJADI?}

Beberapa penelitian terkait penyakit zoonosis yang akhir-akhir berkembang dengan sangat cepat (Wijayanti, 2010), menunjukan bahwa dalam kerangka besar terjadinya kasus seperti ini sebenarnya terkait dengan deforestasi dan degradasi habitat (Nasi et al., 2020). Kondisi tersebut kemudian memicu isolasi lingkungan yang mendorong lompatan penyakit dari satwa pada manusia.

Dalam sebuah penelitian lebih baru, tim peneliti CIFOR menunjukan bahwa populasi kelelawar di hutan hujan Afrika terganggu oleh manusia. Peningkatan kontak dengan manusia mempengaruhi penyebaran Ebola atau penyakit lain yang dibawa oleh kelelawar (Nasi et al., 2020). Pada akhirnya penularan terjadi dengan sangat cepat, karena habitat kelelawar menjadi dekat dengan pemukiman manusia.

Transmisi penyakit antara satwa pada manusia bukan hal baru. Menurut Pusat Pengendalian dan Pencegahan Penyakit AS, satwa merupakan vektor dari lebih 60 persen penyakit menular. Lembaga ini juga menyatakan bahwa tiga dari setiap empat penyakit menular baru atau yang tengah berkembang bersifat zoonosis (Nasi et al., 2020). Tren penularan yang sangat cepat umumnya dikarenakan oleh dekatnya habitat mereka dengan keseharian kehidupan manusia.

Bagi para pemerhati dan pelaku konservasi satwa, wabah C-19 ini bermanfaat bagi satwa liar, karena masyarakat tidak lagi melakukan perburuan, perdagangan dan mengonsumsi daging satwa 
liar. Adanya Pembatasan Sosial Berskala Besar (PSBB) menahan laju akses para pedagang dan pemburu ke titik-titik masuk wilayah perburuan yang tertutup pada saat ini. Kesemuanya akan bermuara kepada keberlangsungan hidup satwa yang aman dan peningkatan populasi mereka di alam. Di sisi lain, akibat dari perambahan hutan, perburuan dan perdagangan illegal akan mempengaruhi interaksi manusia-satwa yang berdampak terhadap kesehatan manusia itu sendiri.

\section{INTERAKSI DENGAN PENDENGAR}

Setelah mendengar narasi yang disajikan di awal siaran, dan dilanjutkan dengan diskusi antara nara sumber dengan pemandu siaran, para pendengar melakukan interaksi dengan memberikan tanggapan dan mengajukan pertanyaan seputar isu yang didiskusikan. Secara berurutan tanggapan dan pertanyaan yang diajukan adalah sebagai berikut:

1. Kejadian awal terjadinya di Wuhan, apakah mungkin kelelawar yang ada di daerah ini juga menjadi penyebab Covid-19 di Manokwari. Respon: yang menjadi kekuatiran kita semua karena penyakit zoonosis yang akhir-akhir berkembang dengan sangat cepat. Mobilitas manusia dari satu tempat ke tempat yang lain tanpa mempedulikan protokol kesehatan yang sudah ditetapkan, memungkinkan terjadinya penularan penyakit zoonosis dari hewan ke manusia atau sebaliknya dari manusia ke hewan. Karena itu kemungkinan ini bisa saja terjadi di Manokwari.

2. Kami di rumah memelihara burung paruh bengkok sebagai hewan kesenangan, apa yang harus kami lakukan untuk mencegah penyebaran penyakit ini? Respon: Menjaga kebersihan burung dengan selalu mengganti tempat makan dan minum yang sudah kotor. Melakukan pembersihan tempat bertengger burung dan selalu keadaan sekitar dijaga kebersihannya. Sebisa mungkin dihindari adanya hewan liar dari luar ikut bertengger di tempat peliharaan.

3. Semua mahluk hidup sudah diberikan tempat untuk hidup. Satwa juga punya habitat yang ditempati untuk keperluan hidupnya. Pembukaan hutan yang dikonversi untuk berbagai tujuan menghilangkan tempat hidupnya. Perlu ada penyuluhan bagi pihak-pihak yang membuka hutan sehingga membuka peluang ekspose satwa terhadap manusia semakin tinggi. Respon: Perangkat perundang-undangan semuanya telah tersedia untuk mengatur aktivitas masyarakat. Perlu kesadaran yang tinggi dari kita semua untuk bisa mengendalikan diri kita sendiri, dan menjadi contoh bagi orang lain.

4. Selama ini kami memanfaatkan sumberdaya satwa liar untuk konsumsi rumah tangga. Apakah dengan kondisi pandemik saat ini hal tersebut tidak boleh dilakukan? Respon: Sebisa mungkin saat ini konsumsi daging satwa dibatasi atau dikurangi. Jika dikonsumsi, 
peroses pengolahan daging harus benar-benar higienis dan memenuhi syarat kesehatan. Hal ini akan membantu mengurangi penyebaran virus Covid-19.

5. Apakah sudah ada penelitian yang dilakukan di Manokwari dalam kaitannya dengan penyebaran virus Covid-19 dalam kaitannya dengan satwa liar yang ada? Respon: Sampai sejauh ini belum ada penelitian tentang penyebaran virus Covid-19 oleh satwa liar di Manokwari. Tetapi momen ini hendaknya menjadi peringatan dini bagi kita semua untuk berhati-hati dan mengantisipasi penyebaran virus ini di sekitar kita.

6. Bagaimana peran akademisi di Universitas Papua dalam upaya membantu mengurangi penyebaran virus Covid-19 di Manokwari? Respon: Ada yang terlibat langsung dalam aktivitas Gugus Tugas Covid-19 di tingkat Provinsi Papua Barat, ada yang giat dalam kegiatan penyuluhan dan penyadartahuan dalam mengantisipasi penyebaran virus ini, dan terlibat secara langsung dalam kegiatan Pengabdian Pada Masyarakat melalui kegiatan Kuliah Kerja Nyata Merdeka Belajar 2020 di era pandemik Covid-19.

\section{PERINGATAN DINI BAGI KITA}

Dalam kondisi pandemik Covid -19 saat ini, bagaimana sikap dan tindakan kita terhadap kebiasaan, berburu, menjual, memelihara, mengonsumsi bahkan hidup berdampingan dengan hewan liar (hidupan liar) perlu mendapat perhatian serius. Memang dilematis, di satu sisi kita berusaha hidup aman dan sehat, tetapi di sisi lain ketergantungan yang sangat tinggi terhadap sumber protein hewani asal satwa juga cukup signifikan.

Langkah strategis pemerintah serta aparat tingkat bawah, untuk melakukan sosialisasi bahaya penyakit yang dibawa satwa liar perlu menjadi prioritas saat ini. Hal mana juga bertujuan untuk menyadarkan masyarakat agar tidak lagi berburu dan memperdagangkan satwa liar secara illegal. Bagi masyarakat di pedalaman dengan sumber protein hewani ternak yang terbatas, konsumsi dapat saja dilakukan tetapi dengan proses pengolahan (memasak) yang memenuhi syarat kesehatan dan hygienis. Pelarangan seharusnya dilakukan jika ada alternatif sumber protein hewani lainnya. Bagi yang memelihara satwa sebagai hewan kesayangan (pets) tatalaksana pemeliharaan harus memperhatikan aspek kesehatan dan kesejahteraan hewan tersebut. Kebersihan kandang dan lingkungan perlu diperhatikan dengan baik. Tersedianya pakan yang bergizi dan memenuhi syarat kesehatan perlu diperhatikan. Jauh lebih penting pemantauan kondisi kesehatan hewan peliharaan merupakan prioritas utama pemelihara satwa.

\section{KESIMPULAN}

Penyebaran informasi melalui media elektronik (radio) berkaitan dengan isu pendemi Covid-19 ini, sangat baik dan efektif karena jangkauannya yang luas bagi masyarakat yang bisa mengikuti siaran radio RRI Pro2FM Manokwari. Kedekatan hubungan antara manusia-satwa liar di Papua, 
perlu disikapi dengan bijaksana untuk mendukung program pemerintah dalam penanganan virus Covid-19 di Manokwari. Kegiatan ini memberikan masukan kepada kita bagaimana pemahaman masyarakat terhadap pandemik Covid-19, dan tindak lanjut yang perlu dilakukan oleh pihak-pihak berwenang untuk mengurangi penyebaran virus Covid-19 di masyarakat.

Penyebaran informasi tentang virus Covid-19 secara intens saat ini perlu dilakukan sebagai upaya penyadar tahuan bagi masyarakat awam yang belum memahami dengan baik bahayanya virus ini bagi kesehatan manusia. Bentuk interaksi dengan masyarakat sangat baik untuk mengetahui sejauh mana pemahaman mereka terhadap isu yang disampaikan.

\section{UCAPAN TERIMA KASIH}

Kegiatan ini dapat terlaksana dengan baik atas bantuan dan kerjasama yang baik dengan Program Manokwari Menyapa RRI Pro2FM secara khusus bagian penyiaran (Bapak Herman Lengam). Oleh karena itu penghargaan yang setinggi-tingginya layak diberikan kepada RRI Manokwari sebagai media elektronik yang aktif dalam mendiskusikan topik-topik yang relevan dengan keadaan terkini di Manokwari.

\section{DAFTAR PUSTAKA}

Koibur, J.F., Manik, H., Crysostomus, H.Y., Pattiselanno, F. 2015. Memelihara satwa sebagai hewan kesenangan (Pets) di Manokwari: Potensi atau ancaman? Fauna Indonesia Vol. 14(1): 43-49

McNamara, J., Robinson, E.J.Z., Abernethy, K., Iponga, D.M., Sackey, H.N.K., Wright, J.H. MilnerGulland, E.J. 2020. COVID-19, Systemic Crisis, and Possible Implications for the Wild Meat Trade in Sub-Saharan Africa. Environmental and Resource Economics 76:1045-1066. doi: 10.1007/s10640-020-00474-5

Nasi, R., Mollins, J., Fa, J.E. 2020. COVID-19 pandemic: How nature steps in to refill 'empty forests' when animals disappear. https://forestsnews.cifor.org/65145/covid-19-pandemic-hownature-steps-in-to-refill-empty-forests-when-animals-disappear?fnl=en. Retrieved 20 Mei 2020

Pattiselanno, F. 2006. Perburuan satwa di Papua. Biota Vol. XI(1): 59-61

Pattiselanno, F. 2013. ProfilRusa Timor (Cervus timorensis moluccensis Müller, 1839) yang dipelihara di Manokwari. Fauana Indonesia Vol. 12(2): 61-66

Pattiselanno, F. 2017. Cenderawasih, Kasuari dan Mambruk: Spesies Avifauna yang menjadi ikon Papua. https://fpattiselanno.wordpress.com/2017/12/29/cenderawasih-kasuari-dan-mambrukspesies-avifauna-yang-menjadi-ikon-papua-cenderawasih-kasuari-and-mambruk-avifaunaspecies-as-papua-icon/. Retrived 15 Desmber 2020

Wijaya, C. 2020. Virus kelelawar: Penyakit akibat corona dianggap berasal dari binatang ini, masyarakat diimbau hindari. https://www.bbc.com/indonesia/indonesia-51262379. Retrieved 20 Desember 2020.

Wijayanti, T. 2010. Zoonosis. Balaba Vol. 6(1): 20-21

Zhao, H. 2020. Covid-19 drives new threat to bats in China. Science Vol. 367, Issue 6485, pp. 1436. DOI: $10.1126 /$ science.abb3088 